\title{
BIẾN ĐỔI KHÍ HẬU VÀ NHỮNG TÁC ĐộNG CỦA BIẾN ĐỔI KHÍ HẬU ĐẾN PHÁT TRIỂN BỀN VŨNGG TIỂU VÙNG SINH THÁI VEN BIỂN ĐỒNG BẦNG SÔNG CỦU LONG
}

\author{
Nguyễn Văn Hồng1, Phan Thị Anh Thơ ${ }^{1}$, Nguyễn Thị Phong Lan²
}

Tóm tắt: Bài báo này đánh giá xu thế khi hậu và kịch bản biến đổi khi hậu ở Đồng bằng sông Cưu Long (ĐBSCL). Sư dụng phưong pháp phân tích xu thế nhiệt độ và lương mưa tại 09 trạm khi tương trong giai đoạn 1980 - 2018 và kịch bản biến đổi khí hậu của Bộ Tài nguyên và Môi truờng năm 2016, dụa trên các kịch bản RCP 4.5 và RCP 8.5. Kết quả phân tích cho thấy nhiệt độ trung bình hàng năm trong khu vực tù̀ 23,0 đến $28,0^{\circ} \mathrm{C}$. Nhiệt độ trung bình hàng năm có xu hướng tăng khoảng 0,027 C/năm. Lương mura trung bình trong khu vục khoảng 1250-2450 mm. Với kịch bản RCP 4.5, đầu thế kỷ 21, lương muxa trung bình tăng 4,5 - 35,4\%; vào giũa thế kỷ 21, lựng mua trung bình tăng 5,8 - 20,6\%; cuối thế kỷ 21, lương mura trung bình tăng 9,6-23,8\%. Với kịch bản RCP 8.5, đầu thế kỷ 21, lượng mura trung bình tăng 6,7-27,3\%; vào giũa thế kỷ 21, lương mura trung bình tăng 10,8 - 20,7\%; vào cuối thế kỷ 21, luợng mua trung bình tăng 12,6 - 23,7\%. Bài báo buớc đầu đã nhận diện được nhũng tác động của biến đổi khi hậu đến vùng sinh thái ven biển và các hoạt động kinh tế ở ĐBSCL trong nhũng năm gần đây nhu: hạn hán, thiếu nước, xâm nhập mặn, sạt lở bờ sông, xói lở bò̀ biển.

Từ khóa: Biến đổi khi hậu, kịch bản, tác động biến đổi khi hậu.

Ban Biên tập nhận bài: 12/9/2019 Ngày phản biện xong: 22/10/2019 Ngày đăng bài: 25/11/2019

\section{Mở đầu}

Vùng ven biển Đồng bằng sông Cửu Long (ĐBSCL) có tiềm năng đa dạng, có thế mạnh phát triển nông nghiệp và các ngành kinh tế biển, ven biển, nhất là nuôi trồng và khai thác thủy hải sản. Thời gian qua, kinh tế - xã hội các tỉnh trong vùng đã đạt được những thành tựu quan trọng, kết cấu hạ tầng được quan tâm đầu tư xây dựng, quốc phòng - an ninh được giữ vững, đời sống nhân dân từng bước được cải thiện và nâng lên. Tuy nhiên, những năm gần đây, các tỉnh trong vùng đã và đang phải đối mặt với tác động ngày càng mạnh mẽ của biến đổi khí hậu. Biểu hiện rõ nét là nhiệt độ tăng cao, hạn hán khốc liệt, xâm nhập mặn sâu vào nội đồng, lốc xoáy diễn ra thường xuyên, triều cường và sạt lở bờ sông, bờ biển diễn biến phức tạp. Các tỉnh vùng ven biển ĐBSCL thực sự đang là những địa phương bị tổn thương nhiều nhất do biến đổi khí hậu gây ra.
Dân cư sống rải rác, dễ bị ảnh hưởng trước tác động của biến đổi khí hậu và nước biển dâng, nên công tác phòng, tránh thiên tai, bảo vệ sản xuất, cung cấp nước ngọt, phát triển kinh tế, nâng cao đời sống nhân dân gặp không ít khó khăn, tốn kém. Chính vì vậy, các tỉnh này đã, đang chịu tác động nặng nề nhất so với các tỉnh trong khu vực và đang phải đối mặt với những thách thức.

\section{Phương pháp nghiên cứu và thu thập tài} liệu

\subsection{Giới thiệu khu vục nghiên cúu}

Khu vực nghiên cứu là khu vực ven biển Đồng bằng sông Cửu Long. Vùng ven biển Đồng bằng sông Cửu Long (ĐBSCL) có tiềm năng đa dạng, có thế mạnh phát triển nông nghiệp và các ngành kinh tế biển, ven biển, nhất là nuôi trồng và khai thác thủy hải sản. 


\section{BÀI BÁO KHOA HỌC}

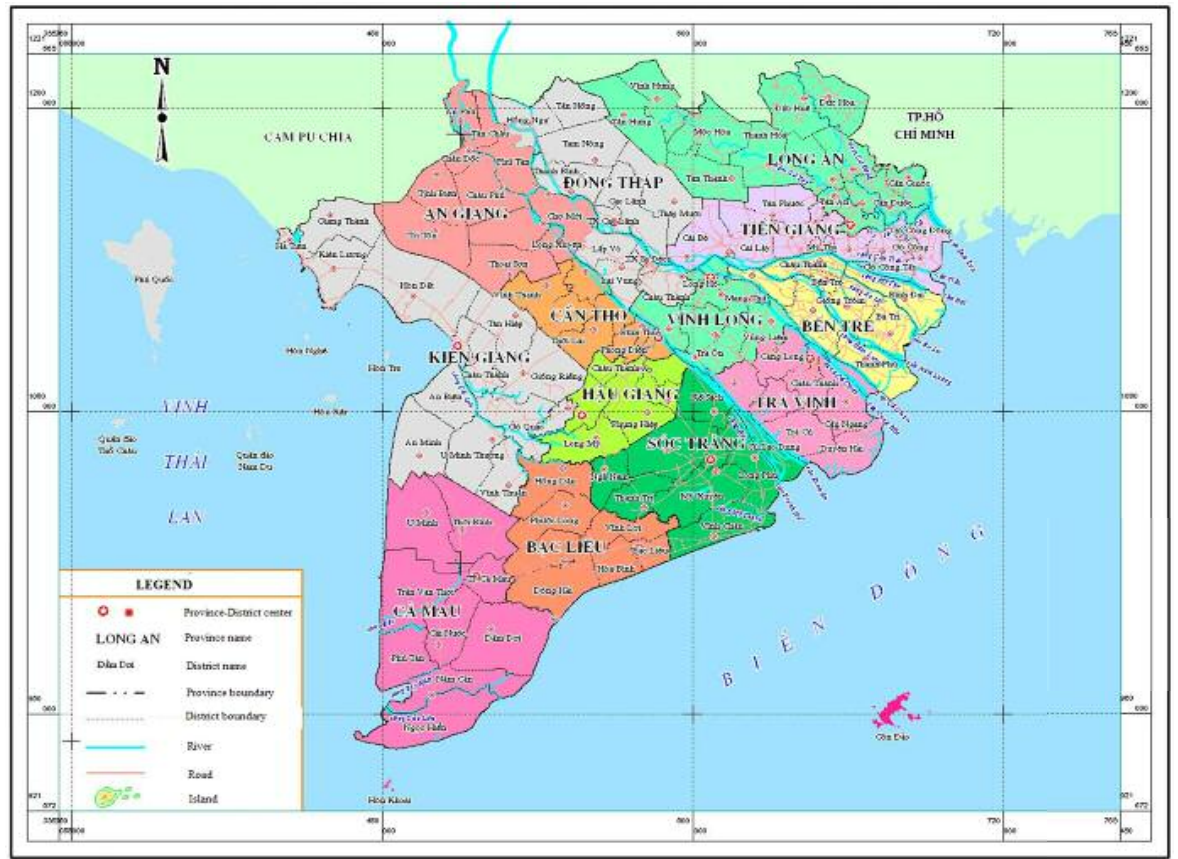

Hình 1. Vị trí địa lý khu vục đồng bằng sông Cửu Long [6]

\subsection{Phương pháp nghiên cứu}

Phương pháp hồi quy tuyến tính được sử dụng để xác định xu thế và mức độ biến đổi của các biến khí hậu. Số liệu thực đo về nhiệt độ, lượng mưa tại 9 trạm khí tượng, thủy văn,... được dùng để phân tích xu thế và mức độ biến đổi của các biến khí hậu lượng mưa và nhiệt độ trong quá khứ (1980 - 2017).

Bài báo xây dựng kịch bản Biến đổi khí hậu tại khu vực Nam Bộ cho nhiệt độ trung bình năm và lượng mưa năm dựa vào kịch bản biến đổi khí hậu của Bộ Tài nguyên và Môi trường năm 2016, dựa trên các kịch bản RCP 4.5 và $\mathrm{RCP}$ 8.5. Phương pháp chi tiết hóa động lực là phương pháp chính được sử dụng để tính toán xây dựng kịch bản biến đổi khí hậu cho Nam Bộ.

\subsection{Số liệu sử dụng để đánh giá}

Việc đánh giá sự biến đổi của nhiệt độ, lượng mưa tại khu vực nghiên cứu được tiến hành tại một số trạm khí tượng chính ở khu vực ĐBSCL, với chuỗi số liệu tin cậy và có đủ độ dài để phục vụ tính toán thống kê, các trạm điển hình được sử dụng là: Tân Sơn Hòa, Vũng Tàu, Biên Hòa, Sở Sao, Mộc Hóa, Cần Thơ, Châu Đốc, Rạch Giá, Cà Mau giai đoạn 1980-2017.

Kịch bản biến đổi khí hậu và nước biển dâng cho khu vực Nam Bộ được xây dựng trên cơ sở dựa vào kịch bản biến đổi khí hậu của Bộ Tài nguyên và Môi trường năm 2016, các kịch bản RCP 4.5 và RCP 8.5 , bản đồ số địa hình quốc gia cập nhật đến năm 2015; xu thế biến đổi gần đây của khí hậu và nước biển dâng ở Việt Nam; các mô hình khí hậu toàn cầu và mô hình khí hậu khu vực độ phân giải cao cho khu vực Việt Nam, các mô hình khí quyển - đại dương [3].

\section{Kết quả và thảo luận}

\subsection{Biến đổi khí hậu ở khu vục Đồng bằng} sông Cửu Long

3.1.1. Xu thế biến đổi các yếu tố khi hậu tại khu vực Đồng bằng sông Cưu Long

a) Nhiệt độ

Theo số liệu quan trắc trung bình nhiều năm (1980 - 2017) tại các trạm điển hình thuộc khu vực Đồng bằng sông Cửu Long, nhiệt độ có xu thế tăng với tốc độ trung bình khoảng $0,027^{\circ} \mathrm{C} /$ năm.

Theo số liệu quan trắc nhiệt độ hơn 30 năm (1980 - 2017), nhiệt độ TBNN tại khu vực Đồng bằng sông Cửu Long khoảng từ $23,0 \div 28,0^{\circ} \mathrm{C}$. Nhiệt độ có xu thế tăng với tốc độ trung bình $0,027^{\circ} \mathrm{C} /$ năm. Khu vực miền Đông tăng nhanh hơn khu vực miền Tây. Nhiệt độ phân bố không đều. Nhìn chung, khu vực miền Đông có nhiệt độ TBNN thấp hơn khu vực miền Tây. 


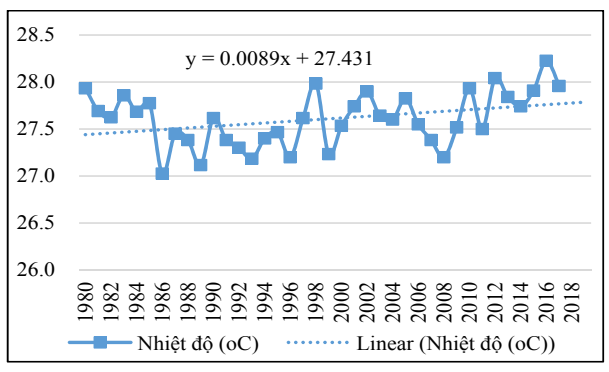

a) Rạch Giá

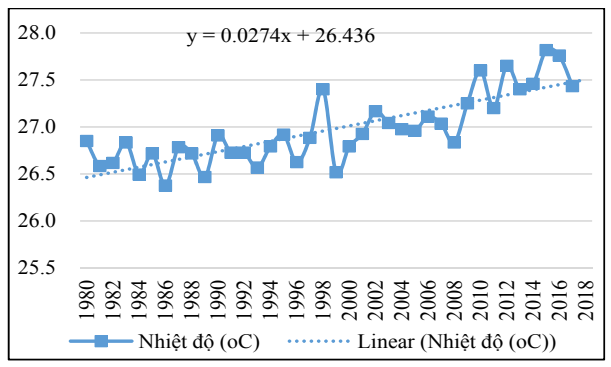

c) Cần Tho'

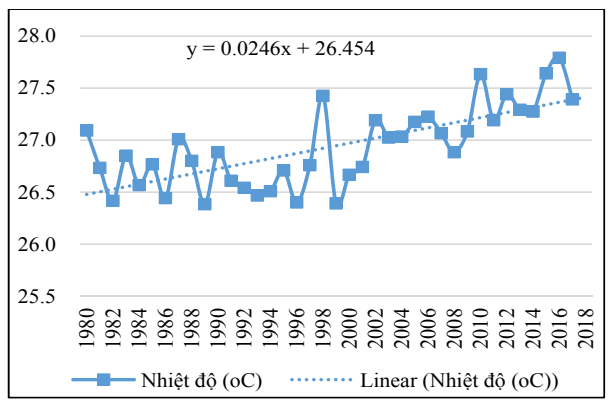

e) Bạc Liêu

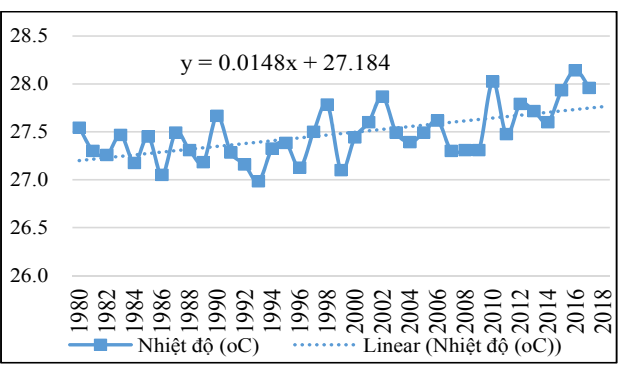

b) Mộc Hóa

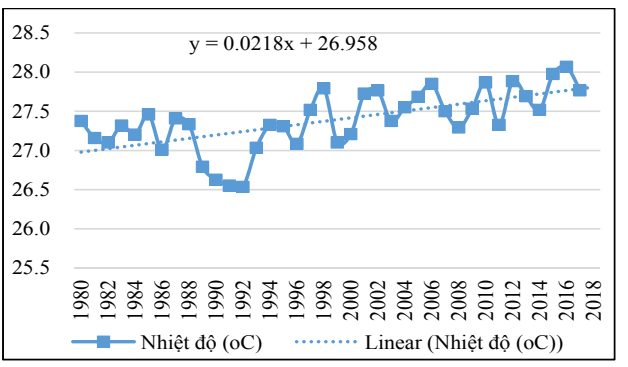

d) Châu Đốc

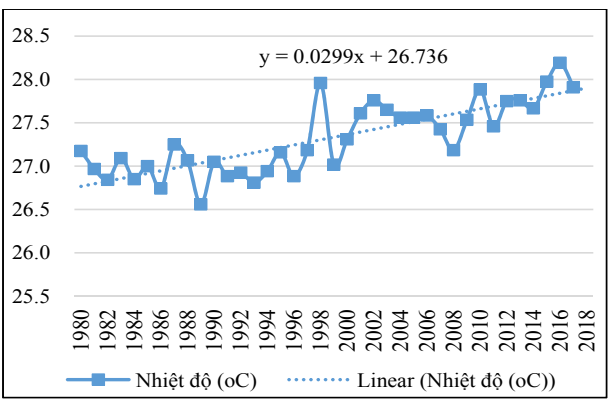

f) Cà Mau

Hình 2. Xu thế biến đổi nhiệt độ trung bình năm $\left({ }^{\circ} \mathrm{C}\right)$ tại khu vực Đồng bằng sông Cưu Long giai đoạn 1980 - 2017

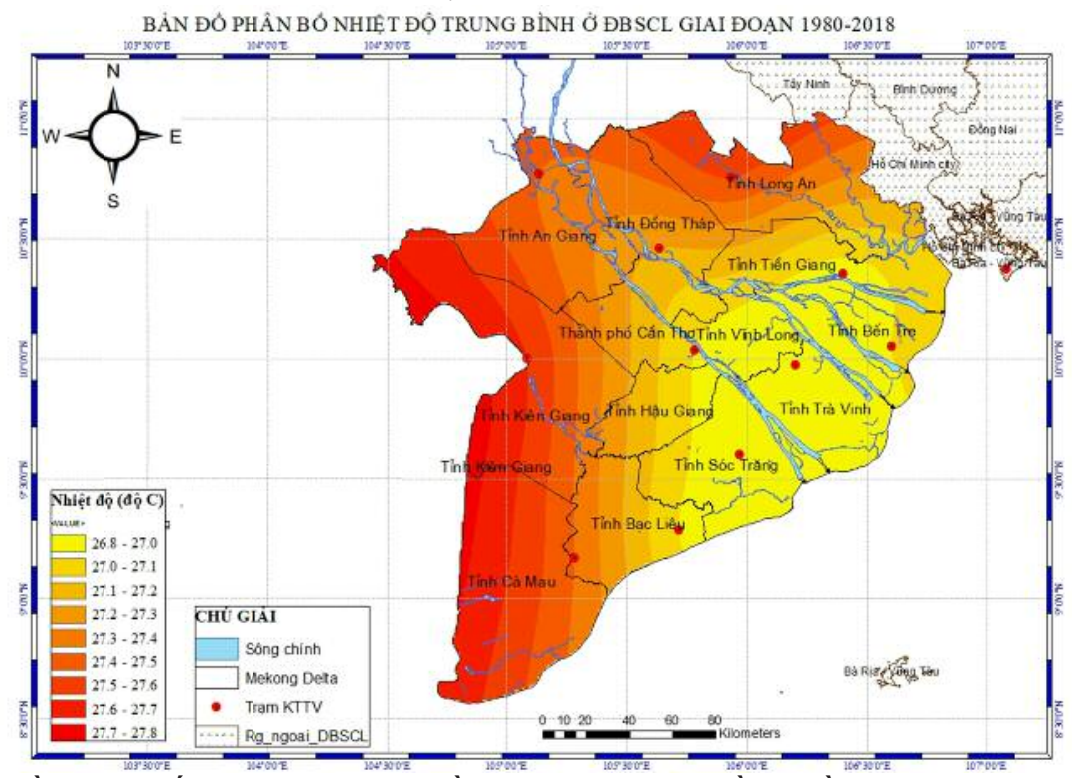

Hình 3. Bản đồ phân bố nhiệt độ trung bình tại khu vực Đồng bằng sông Cửu Long giai đoạn $1980-2018$

b) Lương mưa

Số liệu quan trắc TBNN (1980 - 2017) tại các trạm thuộc khu vực Đồng bằng sông Cửu Long cho thấy lượng mưa thể hiện xu thế tăng, giảm không rõ ràng. Lượng mưa TBNN tại khu vực Đồng bằng sông Cửu Long khoảng từ 


\section{BÀI BÁO KHOA HỌC}

$1250 \div 2450 \mathrm{~mm}$.

Lượng mưa phân bố không đều. Các tỉnh tỉnh phía nam tỉnh Kiên Giang, Bạc Liêu, Cà Mau có lượng mưa trung bình nhiều năm cao, khoảng 2050 - 2450 mm. Những khu vực có lượng mưa

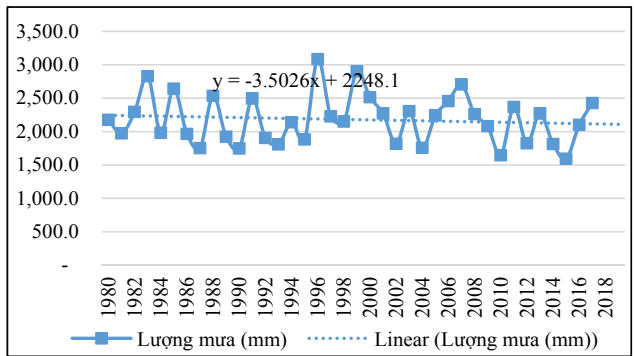

a) Rạch Giá
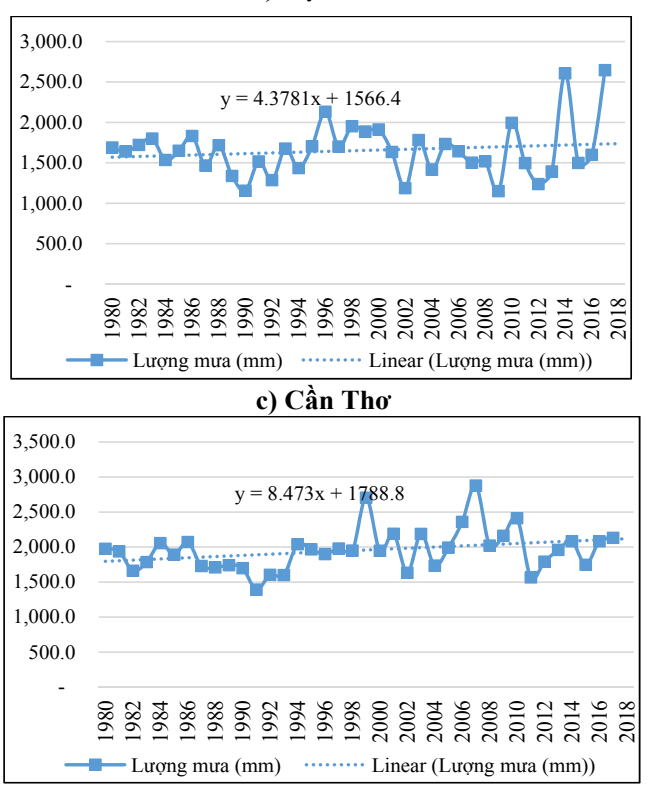
e) Bac Liêu trung bình nhiều năm thấp như: Đồng Tháp, Tiền Giang, Bến Tre, một phần tỉnh Vĩnh Long và An Giang lượng mưa trung bình nhiều năm chỉ khoảng 1250 - $1450 \mathrm{~mm}$.

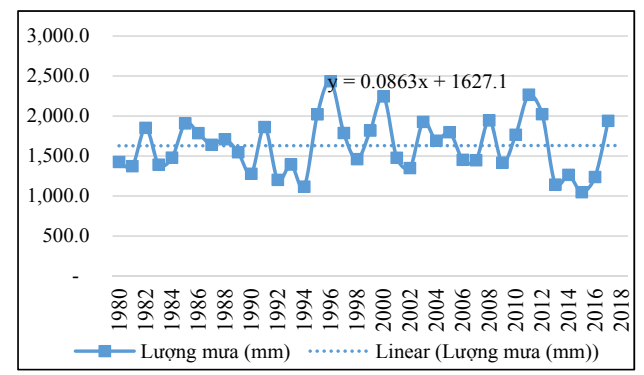

b) Mộc Hóa

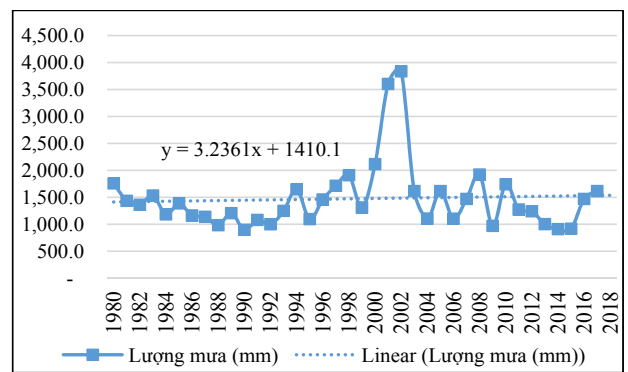

d) Châu Đốc

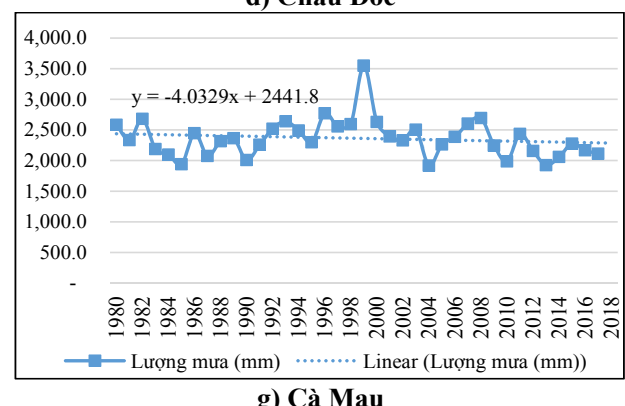

Hình 4. Xu thế biến đổi lượng mura năm (mm) tại khu vục Đồng bằng sông Cửu Long giai đoạn $1980-2017$

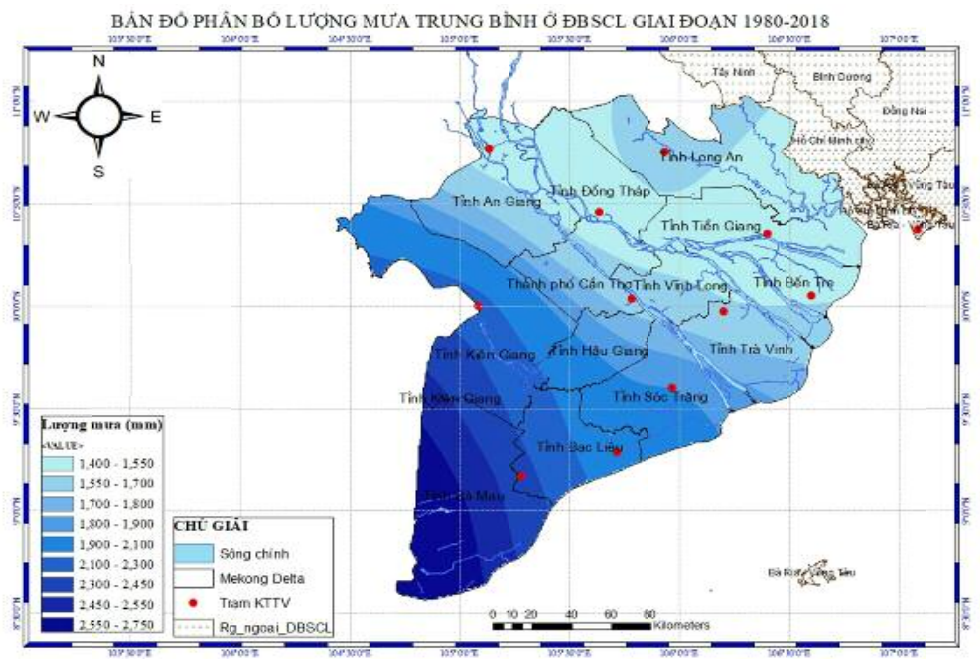

Hình 5. Bản đồ phân bố lượng mưa trung bình tại khu vực Đồng bằng sông Cửu Long giai đoạn $1980-2018$ 


\subsubsection{Kịch bản biến đổi khí hậu cho khu vực Đồng bằng sông Cửu Long}

a) Kịch bản nhiệt độ

Theo kịch bản RCP4.5, vào đầu thế kỷ 21 nhiệt độ trung bình khu vực Đồng bằng sông Cửu Long tăng từ $0,6-0,8^{\circ} \mathrm{C}$; đến giữa thế kỷ 21 , nhiệt độ trung bình tăng từ $1,4-1,6^{\circ} \mathrm{C}$, tăng ít hơn ở khu vực ven biển; đến cuối thế kỷ 21 , nhiệt độ trung bình khu vực các tỉnh ĐBSCL tăng từ $1,8-2,0^{\circ} \mathrm{C}$. Theo kịch bản $\mathrm{RCP} 8.5$, vào đầu thế kỷ 21 nhiệt độ trung bình khu vực tăng từ $0,7-0,9^{\circ} \mathrm{C}$; đến giữa thế kỷ 21 , nhiệt độ trung bình các tỉnh ĐBSCL tăng từ $1,7-2,1^{\circ} \mathrm{C}$, tăng ít hơn ở khu vực ven biển; đến cuối thế kỷ 21 , nhiệt độ trung bình khu vực các tỉnh ĐBSCL tăng 3,3 $-3,5^{\circ} \mathrm{C}[1]$, [5].

b). Kịch bản lượng mưa

Về lượng mưa, theo kịch bản RCP4.5, vào đầu thế kỷ 21 lượng mưa trung bình khu vực các tỉnh ĐBSCL tăng từ 4,4 - 22,4\%; đến giữa thế kỷ 21 , lượng mưa trung bình các tỉnh ĐBSCL tăng từ 5,8 - 20,6\%; đến cuối thế kỷ 21 , lượng mưa trung bình khu vực các tỉnh ĐBSCL tăng từ 9,6 - 23,8\%. Theo kịch bản RCP8.5, vào đầu thế kỷ 21 , lượng mưa trung bình khu vực các tỉnh ĐBSCL tăng từ 6,7 - 17,9\%; đến giữa thế kỷ 21 , lượng mưa trung bình các tỉnh ĐBSCL tăng từ $10,8-20,7 \%$; đến cuối thế kỷ 21 , lượng mưa trung bình khu vực các tỉnh ĐBSCL tăng từ $12,6-23,7 \%$.

ĐBSCL, nhiệt độ có xu thế tăng với tốc độ trung bình $0,27^{\circ} \mathrm{C} /$ năm. Lượng mưa thể hiện xu thế tăng, giảm không rõ ràng [2].

Về nhiệt độ, theo kịch bản RCP4.5, vào đầu thế kỷ 21 nhiệt độ trung bình khu vực các tỉnh ĐBSCL tăng từ $0,6-0,8^{\circ} \mathrm{C}$; đến giữa thế kỷ 21 , nhiệt độ trung bình các tỉnh ĐBSCL tăng từ 1,4 $-1,6^{\circ} \mathrm{C}$, tăng ít hơn ở khu vực ven biển; đến cuối thế kỷ 21 , tăng nhiệt độ trung bình khu vực các tỉnh ĐBSCL tăng từ $1,8 \div 2,0^{\circ} \mathrm{C}$. Theo kịch bản RCP8.5, vào đầu thế kỷ 21 nhiệt độ trung bình khu vực tăng từ $0,7-0,9^{\circ} \mathrm{C}$; đến giữa thế kỷ 21 , nhiệt độ trung bình các tỉnh ĐBSCL tăng từ 1,7 $-2,1^{\circ} \mathrm{C}$, tăng ít hơn ở khu vực ven biển; đến cuối thế kỷ 21 , tăng nhiệt độ trung bình khu vực các tỉnh ĐBSCL tăng từ $3,3-3,5^{\circ} \mathrm{C}$.
Về lượng mưa, theo kịch bản RCP4.5, vào đầu thế kỷ 21 lượng mưa trung bình khu vực các tỉnh ĐBSCL tăng từ $4,4-22,4 \%$; đến giữa thế kỷ 21, lượng mưa trung bình các tỉnh ĐBSCL tăng từ 5,8 - 20,6\%; đến cuối thế kỷ 21 , lượng mưa trung bình khu vực tăng từ 9,6 - 23,8\%. Theo kịch bản RCP8.5, vào đầu thế kỷ 21 lượng mưa trung bình khu vực các tỉnh ĐBSCL tăng từ 6,7 - 17,9\%; đến giữa thế kỷ 21 , lượng mưa trung bình các tỉnh ĐBSCL tăng từ 10,8 - 20,7\%; đến cuối thế kỷ 21 , lượng mưa trung bình khu vực các tỉnh ĐBSCL tăng từ 12,6 - 23,7\%[1], [5].

3.2. Tác động của BĐKH đến vùng sinh thái ven biển Đồng bằng sông Cửu Long

3.2.1 Những thách thức ở vùng đồng bằng sông Cưu Long

ĐBSCL cũng luôn đối mặt với những vấn đề về: lũ và ngập lụt ở vùng thượng; xâm nhập mặn ở vùng ven biển; đất phèn và sự lan truyền nước chua ở những vùng trũng thấp; thiếu nước ngọt cho sản xuất và sinh hoạt ở những vùng gần biển; xói lở bờ sông, bờ biển xảy ra ở nhiều nơi và ngày càng trở nên nghiêm trọng và ô nhiễm nguồn nước, kể cả nước mặt và nước ngầm.

Biến đổi khí hậu ở Việt Nam gây ra các hiện tượng cực đoan như hạn hán gia tăng trong mùa khô, ảnh hưởng của El Nino và La Nina,... Xu thế biến đổi này đang làm thay đổi vòng tuần hoàn của nước trong tự nhiên và do vậy tác động lớn đến tài nguyên nước. Thay đổi chế độ dòng chảy trong sông và triều cường sẽ ảnh hưởng trực tiếp tới phạm vi xâm nhập mặn tại ĐBSCL, đặc biệt trong những năm kiệt. Theo kịch bản biến đổi khí hậu năm 2016, nếu mực nước biển dâng $100 \mathrm{~cm}$ và không có các giải pháp ứng phó, ĐBSCL là khu vực có nguy cơ ngập đến 38,9\% diện tích. Trong đó, các tỉnh có nguy cơ ngập cao nhất là Hậu Giang $(80,62 \%)$, Kiên Giang (76,86\%) và Cà Mau (57,69\%) [2].

Dự báo dân số có thể tăng từ 17 triệu hiện nay lên đến khoảng 30 triệu vào năm 2050, công nghiệp hóa, đô thị hóa sẽ ngày càng phát triển và sẽ thu hẹp diện tích đất nông nghiệp, đồng thời làm tăng nhu cầu về nước sạch cũng như phát sinh nhiều nước thải hơn. Đây sẽ là áp lực lớn đối với nguồn nước của ĐBSCL, đặc biệt là giải 
quyết vấn đề nước ngọt, ô nhiễm nguồn nước, nhất là ở các kênh, rạch nhỏ, chảy qua các khu đô thị, khu công nghiệp. Do đó, nhu cầu lương thực và nước ngọt cũng ngày càng tăng, đồng thời kéo theo những vấn đề về suy giảm chất lượng nước, ô nhiễm nguồn nước. Những vấn đề về xung đột giữa nhu cầu nước ngọt cho nông nghiệp và nhu cầu nước mặn, nước lợ để nuôi tôm đang diễn ra ở nhiều nơi.

Việc phát triển hạ tầng chống lũ, thủy lợi, giao thông đô thị, khu công nghiệp... đã làm biến đổi sâu sắc chế độ lũ tại ĐBSCL như vốn có trước đây. Việc phát triển hệ bờ bao, khu dân dân cư vượt lũ... làm giảm không gian chứa lũ, thoát lũ làm gia tăng nguy cơ ngập, lụt ở nhiều khu vực. Diện tích chứa lũ giảm đồng thời mực nước biển dâng sẽ làm tăng mực nước lũ ở khu vực trung tâm ĐBSCL trong thời gian dài. Ở các khu vực trung và hạ lưu ĐBSCL, do phát triển công nghiệp và đô thị hóa cao, diện tích chứa lũ giảm và nước biển dâng làm tăng nguy cơ ngập lũ.

Cung cấp nước sạch chỉ đảm bảo được cho 60 - 65\% dân số đô thị và tỷ lệ này thấp hơn rất nhiều đối với nông thôn. Nguồn nước để cấp nước ở các khu vực nông thôn đang phải đối mặt với hai vấn đề lớn là mặn và ô nhiễm nguồn nước. Nước thải chưa được xử lý, ô nhiễm công nghiệp và cơ sở hạ tầng sinh hoạt hạn chế gây ra các vấn đề về chất lượng nước và những rủi ro về sức khỏe, đồng thời không đảm bảo việc cung cấp nước. Nếu không kiểm soát hiệu quả các vấn đề về xử lý nước thải, chất thải thì trong tương lai không xa nhiều nơi có nước nhưng không thể sử dụng do bị ô nhiễm, đặc biệt là các kênh, rạch nhỏ. Bên cạnh đó, hệ thống ngăn mặn, giữ ngọt chưa đồng bộ hoặc việc vận hành chưa hợp lý cũng sẽ là vấn đề lớn trong việc bảo đảm nguồn nước ngọt cho canh tác và sinh hoạt.

Sự gia tăng dân số tăng nhanh và việc phát triển nông nghiệp, nuôi trồng thủy sản trong những thập kỷ qua đã làm giảm đáng kể giá trị tự nhiên của ĐBSCL. Nhiều vùng đất ngập nước như rừng ngập mặn, ao, hồ, đầm phá và vùng đồng cỏ ẩm ướt đang biến mất để nhường chỗ cho hệ thống tưới tiêu, trồng rừng, ruộng muối, phát triển công nghiệp và nuôi tôm. Ngoài ra, việc khai thác quá mức tài nguyên thiên nhiên là một mối đe dọa lớn đối với hệ sinh thái.

Việc cải tạo đất và nước, thâm canh nông nghiệp, cùng với tác động sinh thái tiêu cực do chiến tranh để lại đã làm giảm đáng kể diện tích rừng tự nhiên, đất ngập nước và các môi trường sống tự nhiên khác của ĐBSCL. Do có các công trình bảo vệ bờ ven biển nên diện tích các khu vực ngập triều ven biển bị thu hẹp, làm cho diện tích rừng ngập mặn ngày càng giảm đi và điều này làm cho tình hình xói lở bờ biển ngày càng nghiêm trọng hơn.

Diện tích rừng ngập mặn đang bị thu hẹp lại, gia tăng diện tích nuôi tôm, nhất là khai thác nước ngầm bị mặn để nuôi trồng thủy sản... đang làm phức tạp thêm tình hình nhiễm mặn, nhất là các khu vực ven biển.

Các công trình thủy điện đã xây dựng và đang vận hành của Trung Quốc trên sông Lan Thương đã tác động mạnh mẽ đến chế dòng chảy cả mùa lũ và mùa cạn, làm suy giảm hàm lượng phù sa. Chỉ riêng 02 hồ lớn là Tiểu Loan và Nộ Trác Độ đã có dung tích khoảng 38 tỷ $\mathrm{m}^{3}$. Với lượng nước này, nếu xả liên tục 07 tháng mùa cạn, mỗi ngày hạ lưu sẽ có thêm khoảng 180 triệu $\mathrm{m}^{3}$, tương đương khoảng $2100 \mathrm{~m}^{3} / \mathrm{s}$ hoặc ngược lại nếu các hồ không vận hành thì ĐBSCL sẽ không có lượng nước đó.

Theo "Nghiên cứu tác động của các công trình thủy điện trên dòng chính sông Mê Công", khi các công trình thủy điện của Trung Quốc đi vào vận hành thì tổng lượng phù sa bùn cát hàng năm từ Trung Quốc về tới Tân Châu và Châu Đốc giảm từ 73 triệu tấn xuống còn 42 triệu tấn (giảm 42\%).

Tác động của phát triển thủy điện và khai thác sử dụng nước ở thượng nguồn phía Lào, Campuchia và Thái Lan. Theo kết quả "Nghiên cứu tác động của các công trình thủy điện trên dòng chính sông Mê Công" cho thấy các bậc thang thủy điện dòng chính dự kiến sẽ gây nhiều tác động bất lợi ở mức lớn tới nghiêm trọng, nếu không có các biện pháp giảm thiểu. Đó là các vấn đề về suy giảm dòng chảy mùa cạn trong thời đoạn ngắn hạn; suy giảm phù sa, bùn cát (tổng lượng phù sa bùn cát và dinh dưỡng bị giảm tới $65 \%$ và nếu tính chung cả các thủy điện thượng nguồn phía Trung Quốc thì lượng phù sa 
về ĐBSCL chỉ còn lại khoảng 15 triệu tấn, chưa đến $10 \%$ so với điều kiện tự nhiên); xâm nhập mặn sẽ gia tăng tại hầu hết các vùng ven biển. Tác động lên chế độ dòng chảy gây tác động về xâm nhập mặn lớn nhất; làm suy giảm nguồn lợi thủy sản, đa dạng sinh học và gây bất lợi cho hoạt động giao thông thủy trên toàn tuyến.

Một vấn đề đáng quan ngại là hệ thống các hồ chứa trên toàn lưu vực với tổng dung tích rất lớn, khoảng 60 tỷ $\mathrm{m}^{3}$. Nếu lượng nước này được xả liên tục trong 7 tháng mùa cạn thì mỗi ngày hạ lưu sẽ có thêm khoảng 280 triệu $\mathrm{m}^{3}$, tương đương khoảng $3.300 \mathrm{~m}^{3} / \mathrm{s}$.

3.2.2 Nhũ̃ng tác động của BĐKH đến phát triển bền vũng tiểu vùng sinh thái ven biển và hải đảo ở $Đ B S C L$

Những biểu hiện về ảnh hưởng của biến đổi khí hậu đến vùng sinh thái ven biển và hải đảo và các hoạt động kinh tế ở ĐBSCL đã xuất hiện trong những năm gần đây.

\section{Hạn hán, thiếu nước, xâm nhập mặn}

Vào các tháng mùa khô, ĐBSCL chịu tác động mạnh bởi xâm nhập mặn, đây là đặc tính của vùng. Mức độ xâm nhập hàng năm có tính quy luật tương đối rõ rệt, tuy nhiên trong những năm gần đây, nguồn nước thượng lưu sông Mê Công về ĐBSCL đã thay đổi quy luật tự nhiên bởi việc xây dựng, vận hành các hồ chứa thủy điện thượng lưu, dẫn đến xâm nhập mặn có những thay đổi lớn, gây khó khăn lớn trong việc cấp nước phục vụ sản xuất nông nghiệp. Cụ thể

- Thời gian xâm nhập mặn: Có xu hướng xuất hiện sớm hơn trước đây từ 1-1,5 tháng. Giai đoạn trước năm 2012, mặn thường xâm nhập đáng kể từ tháng 2 đến tháng 4 , đỉnh mặn xuất hiện vào cuối tháng 3 hoặc đầu tháng 4 (là tháng có dòng chảy kiệt nhất, gió Chướng hoạt động mạnh nhất). Những năm gần đây dòng chảy thượng nguồn đầu mùa khô về thấp, xâm nhập mặn xuất hiện từ cuối tháng 12 năm trước, đỉnh mặn xuất hiện vào tháng 2; hoặc đầu tháng 3 .

- Phạm vi xâm nhập mặn: Giai đoạn trước năm 2012, ranh mặn $4 \mathrm{~g} / 1$ chỉ vào từ 35 - 45 km, năm sâu nhất đến $60 \mathrm{~km}$. Từ năm 2012 đến nay, xâm nhập mặn với ranh mặn $4 \mathrm{~g} / 1$ thường xuyên vào sâu hơn, ở mức 50 - $60 \mathrm{~km}$, điển hình đợt xâm nhập mặn kỷ lục năm 2016, chiều sâu xâm nhập mặn cao nhất lên tới $90 \mathrm{~km}$. Việc này dẫn đến hàng loại cửa lấy nước được xây dựng trước đây ở khoảng cách cách cửa sông $35-50 \mathrm{~km}$ không thể lấy nước ngọt (trước đây có thể chủ động lấy nước ngọt); ngoài ra, các cửa cống này thường có cửa van tự động đóng mở theo chênh lệnh mực nước thượng/hạ lưu, nên đã gây tác động không nhỏ đến việc chủ động vận hành.
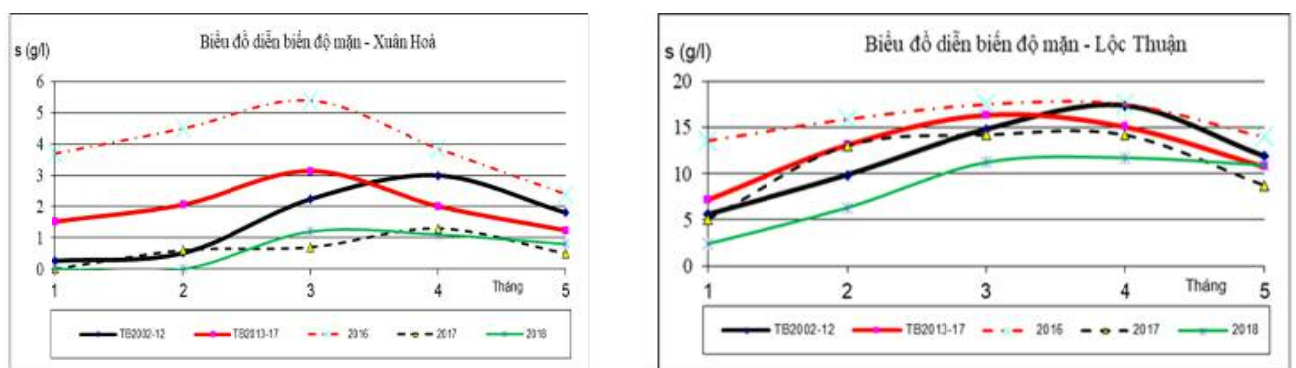

Hình 6. Diễn biến mặn tại trạm điển hình trên sông Của Tiểu, sông Của Đại giai đoạn sau năm 2012 so với truớc đây
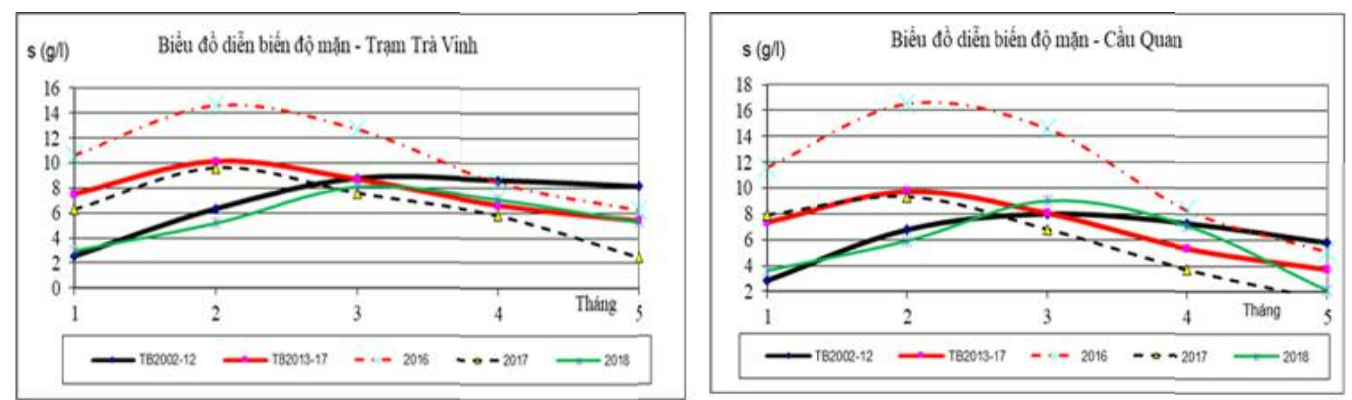

Hình 7. Diễn biến mặn tại trạm điển hình trên sông Cổ Chiên, sông Hậu giai đoạn sau năm 2012 so với truớc đây 


\section{BÀI BÁO KHOA HỌC}

\section{Sạt lở bờ sông, xói lở bờ biển:}

Với các đặc điểm về địa hình, địa chất, tác động của các yếu tố thượng nguồn, từ biển và phát triển vùng đồng bằng, tác động của $\mathrm{BĐKH}$ làm gia tăng sạt lở bờ sông, vùng cửa sông ven biển. Qua công tác theo dõi thấy rằng:

- Giai đoạn trước năm 2010: Vùng ĐBSCL thường xuyên xảy ra hiện tượng sạt lở, tại một số khu vực đã ghi nhận những thiệt hại do sạt lở gây ra, nhất là những khu vực tập trung dân cư như : TX Tân Châu, TP Long Xuyên (An Giang); TX Hồng Ngự; TP. Sa Đéc (Đồng Tháp); TP. Vĩnh Long (Vĩnh Long). Tuy nhiên, xu thế chung là ổn định, không gia tăng quá mức; vùng ven biển có xu thế bồi là chính.

Từ năm 2010 tới nay: Sạt lở diễn biến ngày càng phức tạp và có mức độ gia tăng cả về phạm vi và mức độ nghiêm trọng, uy hiếp trực tiếp đến tính mạng, tài sản của nhân dân, ảnh hưởng nghiêm trọng đến an toàn các công trình phòng chống thiên tai, cơ sở hạ tầng vùng ven biển và làm suy thoái rừng ngập mặn ven biển. Trung bình hàng năm, xói lở dã làm mất khoảng 300 ha đất, rừng ngập mặn ven biển. Theo số liệu thống kê, hiện khu vực ĐBSCL có 564 điểm sạt lở với tổng chiều dài trên $834 \mathrm{~km}$. Trong đó, sạt lở bờ sông 512 điểm với tổng chiều dài khoảng $566 \mathrm{~km}$ (chủ yếu diễn ra dọc theo sông Tiền, sông Hậu, sông Vàm Cỏ Đông, Vàm Cỏ Tây và các nhánh chính của hệ thống kênh, rạch); sạt lở bờ biển 52 điểm với tổng chiều dài $268 \mathrm{~km}$.

Trong số các điểm sạt lở nêu trên, theo tiêu chí về phân loại sạt lở bờ sông, bờ biển quy định tại Quyết định số 01/2011/QĐ-TTg ngày 04/01/2011 của Thủ tướng Chính phủ, hiện có 57 điểm sạt lở đăc biệt nguy hiểm (sạt lở gây nguy hiểm trực tiếp đến khu tập trung dân cư và cơ sở hạ tầng quan trọng), tổng chiều dài 170 $\mathrm{km}$. Bao gồm, bờ sông 39 điểm với tổng chiều dài $85 \mathrm{~km}$, bờ biển 18 điểm với tổng chiều dài $85 \mathrm{~km}$ (biển Đông 15/69km, biển Tây 03 điểm $/ 16 \mathrm{~km})$.

\section{Kết luận}

Các kết quả nghiên cứu về xu thế khí hậu và kịch bản biến đổi khí hậu ở Đồng bằng sông Cửu Long cho thấy:

Nhiệt độ trung bình hàng năm của khu vực Đồng bằng sông Cửu Long khoảng từ 23,0 đến $28^{\circ} \mathrm{C}$. Nhiệt độ trung bình hàng năm có xu hướng tăng khoảng $0,27^{\circ} \mathrm{C} /$ năm. Lượng mưa trung bình khoảng 1250 - $2450 \mathrm{~mm}$. Dựa theo kịch bản biến đổi khí hậu của Bộ TNMT, 2016 cho Đồng bằng sông Cửu Long thì theo các kịch bản RCP 4.5 và RCP 8.5 , nhiệt độ và lượng mưa có xu hướng tăng cả vào giữa và cuối thế kỷ 21 . Với kịch bản RCP 4.5, đầu thế kỷ 21, lượng mưa trung bình tăng 4,5 - 35,4\%; vào giữa thế kỷ 21 , lượng mưa trung bình tăng 5,8 - 20,6\%; cuối thế kỷ 21, lượng mưa trung bình tăng 9,6 - 23,8\%. Với kịch bản RCP 8.5 , đầu thế kỷ 21, lượng mưa trung bình tăng 6,7 - 27,3\%; vào giữa thế kỷ 21 , lượng mưa trung bình tăng 10,8 - 20,7\%; vào cuối thế kỷ 21, lượng mưa trung bình tăng 12,6 - 23,7\%. Bài báo bước đầu đã nhận diện được những tác động của biến đổi khí hậu đến vùng sinh thái ven biển và các hoạt động kinh tế ở ĐBSCL trong những năm gần đây như: Hạn hán, thiếu nước, xâm nhập mặn, sạt lở bờ sông, xói lở bờ biển.

Các nghiên cứu nêu trên là những bước đi đầu tiên có ý nghĩa khoa học và thực tế cao, đặt nền móng về cơ sở dữ liệu và phương pháp luận để đánh giá đề xuất mô hình, giải pháp phát triển bền vững ứng phó với biến đổi khí hậu phù hợp cho các tiểu vùng sinh thái ở ĐBSCL.

Lời cảm ơn: Nhóm nghiên cứu xin chân thành cảm ơn sụ hỗ trợ của đề tài khoa học "Nghiên cứu đề xuất mô hình, giải pháp phát triển bền vững ứng phó với biến đổi khí hậu phù hợp cho các tiểu vùng sinh thái ở đồng bằng sông Cưu Long”, mã số: BĐKH.42/16-20 trong việc thực hiện và công bốnghiên cứu này. 


\title{
Tài liệu tham khảo
}

1. Ministry of Natural Resources and Environment (2016), Climate change and sea level rise scenarios for Vietnam.

2. Southern regional Hydrometeorological (2018), Additional comments on the weather and hydrological trend of the rainy season, storm and flood in 2018 in the South of Vietnam.

3. National Centre for Hydro-Meteorological Forecasting (2018), Updated Report on ENSO and Hydrometeorological status.

4. Institute of Hydrometeorology and Climate Change (2018), Monthly climate forecast for 2018.

5. IPCC (2013), IPCC Fifth Assessment Report: Climate Change 2013 - The Physical Science Basis, Cambridge University Press, Cambridge, UK, pp. 1535.

6. Bộ TN\&MT (2013), Nghiên cưu thiết kế mô hình làng sinh thái thích ứng với BĐKH dựa vào cộng đồng cho khu vục ĐBSCL, Hà Nội.

\section{CLIMATE CHANGE AND THE IMPACTS OF CLIMATE CHANGE ON SUSTAINABLE DEVELOPMENT OF COASTAL REGION IN THE MEKONG DELTA}

\author{
Nguyen Van Hong ${ }^{1}$, Phan Thi Anh Tho', Nguyen Thi Phong Lan ${ }^{2}$ \\ ${ }^{1}$ Sub-Institute of Hydrometeorology and Climate Change (SIHYMECC) \\ ${ }^{2}$ Cuu Long Delta Rice Research Institute (CLRRI)
}

\begin{abstract}
Abtract: This paper reviews the trends of climate and climate change (cc) scenarios in the Mekong delta. Using the trend analysis method of temperature and rainfall at 09 meteorological stations in the period 1980 - 2018 and the climate change scenarios of MONRE in 2016, based on $R C P 4.5$ and $R C P 8.5$ scenarios. The annual average temperature ranges in the region delta from 23.0 to $28.0^{\circ} \mathrm{C}$. The average annual temperatures tend to rise about $0.027^{\circ} \mathrm{C}$ per year. The average rainfall in the region delta is about $1250-2450 \mathrm{~mm}$. With the RCP4.5 scenario, in the early 21 st century, the average rainfall increased by $4.4-22.4 \%$; in mid-21st century, the average rainfall increased by 5.8 - 20.6\%; in end of 21 st century, the average rainfall increased by $9.6-23.8 \%$. With the RCP8.5 scenario, in the early 21 st century, the average rainfall increased by $6.7-17.9 \%$; in mid21 st century, the average rainfall increased by 10.8 - 20.7\%; in end of 21 st century, the average rainfall increased by $12.6-23.7 \%$. The article also has reviewed the impacts of climate change on coastal ecology and economic activities in the Mekong delta in recent years: drought, water shortages, saltwater intrusion, riverbank landslides, coastal erosion.
\end{abstract}

Keywords: Climate change, Scenarios, the impacts of Climate change. 